\title{
$\underline{\operatorname{articles}}$
}

\section{Developing a Small Business Educational Program for Growing Rural Businesses}

\author{
Timothy L. Pett, Ph.D. ${ }^{1}$, John Francis, Ph.D. ${ }^{2}$, ${ }^{\text {b }}$, Wendy Veatch ${ }^{3}$ c \\ ${ }^{1}$ Department of Business, Rollins College, ${ }^{2}$ Fowler College of Business, San Diego State University, ${ }^{3}$ W. Frank Barton School of Business, Wichita \\ State University \\ Keywords: Rural Small Business, Education, Training \\ https://doi.org/10.53703/001c.29476
}

\section{Journal of Small Business Strategy}

Vol. 31, Issue 4, 2021

\begin{abstract}
This paper elaborates on the development of a small business certificate program in rural Kansas. Researchers and local practitioners suggest that there are differences between rural and urban small businesses and that most educational programs do not account for these differences. After exploratory research, the university team identified specific needs facing local businesses and tailored a program for their needs. A program structure and set of topics, paired with faculty experts was developed and implemented. Topics focused on developing an entrepreneurial orientation, as well as certain business fundamentals that were deemed critical to small rural businesses. Each topic was oriented toward the rural context where face to face business is more essential. A feedback loop was implemented leading to a shorter 8-week timeframe and some topic adjustments. To date, 378 firms have participated in the program and have shown an $80 \%$ survival rate. Specific feedback has indicated that business growth has occurred and that the respondents do perceive development in their entrepreneurial orientation. In addition, specific skill areas related to unique businesses have been improved. Lastly, the program participants have grown their regional business networks, which has been shown to be an important factor for rural business success.
\end{abstract}

\section{Introduction}

Throughout rural America, there are tremendous pressures on small businesses and their survival. These include large scale urbanization and a changing competitive marketplace. In addition, many small businesses face higher costs of goods and services, shortage of available qualified workers, poor broadband, competition from big box retailers, and a lack of expertise in social media marketing. These problems have been exacerbated by the COVID-19 pandemic in the past year with the crisis creating a disproportionate toll on underserved rural areas (Love \& Powe, 2020). Rural firms have often been overlooked, with limited attention to their innovation and exporting practices, their ability to secure business advice and support, or their aspirations and performance (Phillipson et al., 2019).

To assist in advancing rural communities, small businesses are often looking for new and improved ways of executing their business models and for finding business tools applicable to their needs. This paper outlines a process developed in a rural community that attempts to begin addressing some of these needs. In addition, the paper pro- vides an outline of a program that provides technical assistance and exposure to the latest practices for running and growing small rural businesses. The paper discusses a learning process used to create a strategy for the delivery of a certificate program as well as for creating a network for rural small businesses.

\section{Setting the Stage}

In 2007, an EF 5 tornado completely wiped out the entire town of Greensburg, Kansas. Reports indicate that the tornado was over 1.5 miles wide and demolished most, if not all the buildings in the town. Greensburg is located on a major east-west highway that experiences high traffic counts and was home to a number of interesting stores and historical stops before the tragedy. Typical of rural America, the residents decided to stay and rebuild using the latest technologies, opening a new hospital and school. Over a two-year time period, the town slowly redeveloped following a LEED certificate strategy and became one of the leading small rural energy efficient towns in the US.

Small businesses slowly returned during this time, but

\footnotetext{
a 1000 Holt Ave - 2779, Winter Park, FL 32789-4499, USA, tpett@rollins.edu

b San Diego State University, San Diego, CA 92182, USA, john.francis@sdsu.edu

c Wichita State University, Wichita, KS 67260-0147, USA, wendy.veatch@wichita.edu
} 
were having issues growing customer bases and promoting their products and services. Poor performance was exacerbated by the 2008 economic recession and its carryover. In 2012, Greenberg city and county economic officials explored options for helping small businesses grow. A request was made by local government to a Midwestern university in close proximity to Greensburg to develop an educational program for small businesses. Focused strategic interventions at the community and business level have long been posited as an important tool for assisting distressed communities (Emery et al., 2004). After some exploratory research, a working agreement was completed around the concept of launching a "Growing Rural Business" certificate program designed to help small businesses in the region. As part of the research, the university team visited local establishments and conducted small focus groups for the purpose of understanding the pressing issues facing these businesses and an examination of their practices and learning. Next, they examined and vetted training program offerings in the region and state. None were found to provide the technical and face-to-face training business owners wanted to receive. Thus, the university, along with other state partners collaborated in creating the certificate program. The program was developed along the lines of other similar programs designed to meet business needs with processes that fit into program constraints (Garrido-Lopez et al., 2018).

\section{Determine Needs - Community Research and Discussions with Rural Business Owners}

Through our research efforts, we identified needs of rural businesses from a technical assistance and program delivery perspective. In addition, we learned from the community economic development leader the need for better techniques on how to run a business specifically as a rural 'clan' community. From our discussions with her (the economic development coordinator), many of these business owners/ operators were familiar with online development opportunities, but felt that face-to-face learning was what they really wanted in their community. In addition, she suggested that rural businesses face challenges that are different from those in an urban setting and the resources available to them are limited. For example, in rural locations, business is mainly conducted in face-to-face business transactions. However, many business owners in the rural community were looking for virtual or online methods for expanding their revenues and offset growing competition without having the skills or means to accomplish these goals.

Researchers have long suggested that rural areas need to be viewed as unique contexts with specific needs (Farja et al., 2017; Martin et al., 2013). According to Brookings Institute data, rural small businesses face additional challenges different from urban businesses such as the lack of access to capital, limited broadband connectivity, and being clustered in industries inordinately impacted by the pandemic such as retail, bars and restaurants (Love \& Powe, 2020). In addition, research on rural business owners indicate that they perceive problems differently than urban entrepreneurs. For example, rural firms are more likely than urban firms to see regulation as a problem, which may impact their motivation for business growth (Lyee \& Cowling,
2015). By accounting for the unique challenges facing rural businesses, we explored these differences as the foundation for creating and structuring the educational training program. Other researchers found that creating a competitive advantage could be achieved for rural businesses by creating a value-orientated strategy that is combining cost controls with unique products and/or services (Rubach \& McGee, 2001).

\section{Available Federal and State Programs}

So, what government training and programs are available to rural businesses? At the same time as the focus groups were conducted, researchers conducted database searches to identify programs and understand the types of assistance that federal, state and local governments provide for small rural businesses. There are a number of federal programs currently available including subsidies, grants, and loan programs across the United States. Farm subsidies are often highly debated politically, but for the rural community, the impact has been to sustain the family farm as a rural business while maintaining a consistent food supply. Subsidies are used to by farmers and agribusinesses to supplement income, manage the supply of agricultural commodities, and influence the cost and supply of such commodities (USDA Rural Development-Subject, 2014). From the nonprofit sector, there are various entities such as Farm Aid, which raises funds by working with famous musicians, such as Willie Nelson, and provides information and opportunities for farmers to receive grants. Farm Aid works with local, regional and national organizations to promote fair farm policies and grassroots organizing campaigns designed to defend and bolster family farm-centered agriculture (Farm Aid, 2014).

Programs geared specifically for non-farm related rural businesses are more limited, but are also available. They include the US General Services Administration also sponsors workshops, classes, seminars, meetings and training programs for small business owners (How GSA Helps Small Businesses, 2014). Another federal program is the Small Business Development Centers (SBDCs), which provides a vast array of technical assistance to small businesses. SBDCs are organized through state government organizations and are administered normally through university and/or colleges. The SBDCs are made up of a unique cooperation of SBA federal funds, state and local governments (GalliDebicella, 2020). However, these SBDC centers can be overwhelmed with clients and programs that are difficult to customize to individual rural business needs.

Another large federal program is the USDA Rural Grant Development Assistance Program (USDA Rural Development-Subject, 2014), which aids through direct or guaranteed loans, grants, technical assistance, research and educational materials for qualified small businesses. The USDA Rural Development program in Kansas specifically supports community-managed lending pools and provides technical assistance to help agricultural producers, such as cooperatives, improve the effectiveness of their operations. Under the Community Empowerment Initiative, the program emphasizes broad-based citizen participation, emphasizing minority or low-income members of the community that 
may have been traditionally underserved (USDA Rural Development-KS Homepage, 2014).

State governments with dispersed rural populations understand the importance of rural business for sustaining rural communities beyond farming. Rural communities are in a unique position for small business growth, because of the entrepreneurial spirit and the need to survive exhibited throughout most of these communities. Vibrant small towns and main streets attract new residents and stabilize a tax base for county operations. However, most states mainly rely on existing organizations and training programs that provide standard approaches for assisting small businesses. For example, the Kansas Department of Commerce (Kansas Department of Commerce, 2014) offers a number of unique programs including the Kansas Capital Multiplier Loan matches up to $9 \%$ of private equity invested through a partner network to eligible businesses in communities across Kansas. Funding is provided through the United States Treasury via the State Small Business Credit Initiative (SS$\mathrm{BCI})$. Additionally, at the state level NetWork Kansas resource partners provide business-building services to entrepreneurs and small businesses. Working with a NetWork Kansas resource partners helps businesses get the prompt, local assistance they need to access all types of resources to start or grow their business (NetworkKansas, 2020). NetWork Kansas offers a statewide resource referral service that enables entrepreneurs and small business owners to connect with the resources they need whether it is in their local community or across the state.

Local economic development agencies vary by communities across states with most having some focus on economic development issues for rural businesses. A number of them offer some general advice on starting a business, training and resources. They also aid in gaining loans, grants and tax-exempt bonds. Business location and site selection assistance, employee recruitment and training assistance are sometimes available. Many communities also have not for profit organizations that provide general business information including Chamber of Commerce's and Rotary Organization to name a couple (The U.S. Small Business Administration, 2019).

Although there are a number of resources available for rural businesses, many of these services have a broad generalist approach and often lack the basic business insight needed by these types of businesses. Current programs aid small businesses with general needs, such as getting access to capital, but do not address the importance of unique local attributes such as the need to be regionally connected to in dispersed, rural markets (Vey \& Love, 2019). Ultimately, few of the government programs accounted for these types of differences and while the Greenberg tornado was the original impetus for aiding the rural business community, the team's research provided additional support for a new program that offered "street-level solutions" to small rural businesses. Based on these findings, Network Kansas collaborated with the university to support the creation of a rural certificate program initially aimed at aiding businesses in Greensburg, KS.

\section{Research Method and Results}

As part of the initial decision on whether to develop a program and subsequent assessments on how to structure it, university researchers conducted exploratory interviews with local officials and development agencies in an effort to gain insight for the need of an assistance program that addresses the differences that rural businesses face. Exploratory research was emphasized due to the desire to tailor the program specifically to the local business community, as well as the lack of agreement by the research community on what skills are most necessary for local rural entrepreneurs to succeed (Dahlstrom \& Talmage, 2018).

After these initial interviews, focus groups were conducted with local business owners. The focus group comprised of nine small business leaders from the surrounding community, of which four were female and five were male. On average, their companies were over 33 years old and the managers/owners had been in their positions an average for fifteen years. The number one concern voiced by this group focused on getting and keeping customers, and the limited size of the local target market. The second group of concerns centered on the economy, timing of cash flow, and ability to attract skilled workers. Lastly, the group raised issues regarding limited resources, technology, financing, and issues facing remote location like limited broadband. To some extent, these are similar issues facing all small businesses in some form or another, however the issues seemed to be of greater importance for rural businesses because of the structural realities of the rural market and the lack of available educational and training for business owners.

Overall, the exploratory research indicated thirty-one topics as areas to develop programmatic content for acquiring rural business expertise. For example, one topic included how to fire in a positive manner. Word-of-mouth in a rural market is critical and to dismiss or fire in a positive light is important for dissipating negativity among the community. Other topics included: negotiation, buying skills (win-win and game theory) nuts and bolts of advertising, purchasing and ad placement, developing a press release, grasping how to structure business financials to avoid pitfalls of combining personal and business financials, and joint marketing to establish an identity for the community and the business.

The university team developed these topics into a structured model clustering relevant material into marketing, management, and financial modules. The purpose was to provide an organized approach that allowed the participants to learn the required topics and to be able to synthesize them together to create deeper understanding. The figure below provides the overall map and logic associated with the program as it was initially developed from the research.

The exploratory interviews and focus groups were developed in conjunction with other secondary research, which aimed at identifying rural business needs and the types of government assistance programs that were available for the rural business community. The initial outcome of this research served as a confirmation for creating the program. In addition, the data served as the basis for developing the 
structure and orientation of the new program.

\section{A Certificate Program for Rural Kansas}

The team developed the training model as a certificate program, delivered by university topical experts, so that rural business owners to walk away from the program with a structured resource guide to refer to during and after the program. The new certificate program provides practical, applied information and examples necessary for today's rural communities. In addition, the program was developed into a model that could be reapplied to multiple rural business communities in an effort to scale the business learning.

The model is a customized eleven-week certificate program that is delivered through the regional university, in conjunction with business faculty. Session were offered each week, lasting about $3 \frac{1}{2}$ to 4 hours, with time for oneon-one discussions with facilitators. A key element for delivering a successful program was faculty involvement. All the faculty put in time needed to develop their topics in relation to the rural business setting. In total eight faculty members participated in the delivery of the certificate program.

The first program centered on developing the necessary mindset of being an entrepreneur in a rural setting. This orientation was a cornerstone element throughout the program's timeline. Next, topics were developed around marketing/consumer behavior and merchandising issues. These were raised as important issues by both the local economic development coordinator and the focus group. In addition, topics related to operational issues employees/legal/finance were grouped together and provided. Lastly, the program was concluded by synthesizing previous topics as the participants worked on their business strategies.

The program was designed so that the previous sessions learning outcomes were built on the following week. Participants were expected to 'work on their business at home' after each session. A small celebration of completion followed the last session with family and guests, including local officials. Instructor schedules and time pressures did play a role in the delivery of the programs.

A decision was made early to keep costs and fees to participants at reduced rates due to the rural nature of the businesses and their resource constraints. To successfully recruit participants and enhance learning opportunities in multiple communities across the state, we coordinated with community and state resource partners to help deliver the program. All partners believed it was important that participants have some 'skin in the game', but costs were offset so as not to be onerous and to provide the most opportunity for the greatest number of businesses.

\section{Sustaining the Program}

The program became successful and was replicated once or twice a year in various rural communities. Each year an appropriate amount of time was established for faculty time and travel, marketing of the program through local economic development officials and the distribution of program materials in the communities. The Table 1 provides the number of programs and number of small rural busi-

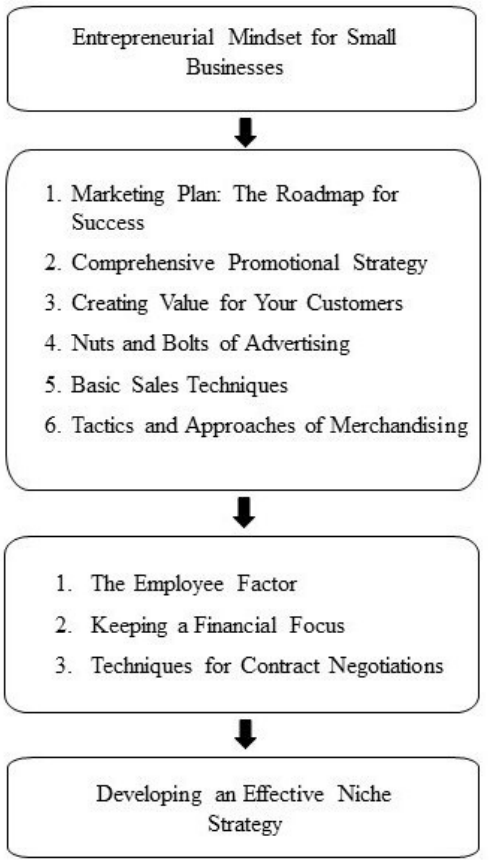

Figure 1. Initial Rural Certificate Program

nesses served since 2012 .

The team of certificate program facilitators who had worked previously with entrepreneurs and small businesses throughout Kansas viewed the program as a viable model for the entire state of Kansas contributing to the long-term success for each community. Continuous feedback and adjustment creating a double-loop process for program development and community support (Senge, 2006) has been used to modify and adjust to individual community needs. The feedback has provided valuable input about program content and as a result, the certificate program was resized to eight modules. Some information was combined, while other information was eliminated as suggested by program participants and in discussion with instructors over a number of sessions. The revised eight-week program has been more desirable by participants due to taking less time away from work, community and family members. The current program model is illustrated in Figure 2.

Over the duration of the certificate program, businesses are encouraged to build their networks through sharing services and doing business with one another. These actions help foster a larger rural business network to include program participants. Events and activities included annual meetings to discuss best practices and networking gatherings across the state.

\section{Program Delivery - Lessons Learned}

In addition to continuing to evolve the content and length of the program, there have been lessons learned regarding how the program is delivered to achieve the best outcomes, both for our participants and for growing the program. These are summarized below:

Program Hours and Timing 
- Offer programs during off-hours to accommodate business owners who are one-person firms.

- Programming time that seems to be best is February through April/May or August through early November.

- Late November through January are not ideal programming times.

\section{Promotion and Distribution of Literature}

- Marketing efforts need to consist of locally respected entrepreneurs, not from the university who is neutral in community. Also, local economic development person who has a solid reputation of making personal visits to businesses in the community has worked well.

- Identify local entrepreneurs to assist in participant recruiting.

- Offer partial scholarships when companies send more than one participant.

- Provide one-year free programming of niche topics for business owners.

\section{Partnering}

- State agencies vested in rural businesses are key for success, such as Network Kansas.

- Local perception is that Chambers of Commerce or local economic development agencies normally do not go outside of their office to engage local businesses.

- Approach local commercial lenders and hold informational luncheons for businesses who are requesting funding or have recently received funding and offer program to these qualified prospects.

- Personal visits in community is critical to enrolling participants in program.

\section{Program Outcomes}

Feedback regarding the Certificate program has been overwhelmingly positive from the participants since its inception. Since its start in 2012, $80 \%$ of program participants are still in business. Although rural new businesses tend to have higher survival rates than their peers in urban communities (Deller \& Conroy, 2017), this compares favorably to the Small Business Administration's (SBA) (2019) statistics regarding failure rates. SBA data suggests that the national failure rate of 1 st year businesses failing at $20 \%$ rate to fifth year businesses failing at roughly $50 \%$.

Participant reaction to the program has come in many forms. We received feedback regarding the quality of the educational experience. For example, Renee of Clay Center, KS commented, "This program was life changing for me and my business. After each class I would take information back to my business and apply it the very next day." Other reactions were more specific to the usefulness of certain types of material. Troy from Andover, KS said, "I thought all sessions especially the Contracts session gave us information that could save us lots of money and better inform us when it comes to reading and making contracts."

In general, we received four basic types of positive feedback from participants that can be categorized in the following manner:
Table 1. Program Participants

\begin{tabular}{|c|c|c|}
\hline $\begin{array}{l}\text { Program } \\
\text { Date }\end{array}$ & Location & $\begin{array}{c}\text { Number of } \\
\text { Business }\end{array}$ \\
\hline Spring 2012 & Greensburg & 21 \\
\hline Fall 2012 & Augusta & 17 \\
\hline Spring 2013 & Dodge City & 20 \\
\hline Winter 2014 & Dodge City & 22 \\
\hline Fall 2014 & Colby & 20 \\
\hline Winter 2015 & Clay Center & 23 \\
\hline \multirow[t]{2}{*}{ Fall 2015} & Marion & 21 \\
\hline & Garnett & 32 \\
\hline Spring 2016 & Phillips County & 23 \\
\hline \multirow[t]{2}{*}{ Fall 2016} & McPherson & 14 \\
\hline & Scott County & 22 \\
\hline \multirow[t]{2}{*}{ Fall 2017} & El Dorado & 16 \\
\hline & Cowley & 24 \\
\hline Spring 2018 & Leavenworth & 16 \\
\hline Fall 2018 & $\begin{array}{l}\text { Rawlins } \\
\text { County }\end{array}$ & 18 \\
\hline Spring 2019 & $\begin{array}{l}\text { Thomas } \\
\text { County }\end{array}$ & 15 \\
\hline Fall 2019 & $\begin{array}{l}\text { Allen \& } \\
\text { Neosho }\end{array}$ & 23 \\
\hline Spring 2020 & Rooks \& Ellis & 17 \\
\hline \multirow[t]{2}{*}{ Fall 2020} & Montgomery & 14 \\
\hline & Total to date & 378 \\
\hline
\end{tabular}

1. The program led to better overall business outcomes. Researchers have not collected comprehensive data, but based on an examination of a subset of 32 firms from one regional area, seventeen indicated revenue growth, adding employees or expanding locations since their participation in the Certificate program.

2 . The program addressed specific elements of the business that helped the participants adjust and improve as aspect of their business. These areas included understanding contracts and legal issues, budgeting, merchandising, and marketing. An example of the type of response.

"The session on merchandising gave me a background on the importance of visual displays, I will be able to now critically observe merchandising displays and more effectively design my own.” - Cindy, Augusta, KS.

3. The program advanced the entrepreneurial mindset of the participants by developing their skills in identifying opportunities, learning from setbacks and determining how to succeed in a variety of settings (Kuratko, Fisher, Audretsch, 2020). As Doreen from Dodge City, KS indicated, “I no longer buy self-help books, instead business books because I now see myself as an entrepreneur!”

4. The program helped participants build their network of local entrepreneurs by introducing them to business people that were interested in the same things or had the same issues to address. "Sharing ideas among attendees of what has worked for them is as valuable as a business owner! It 


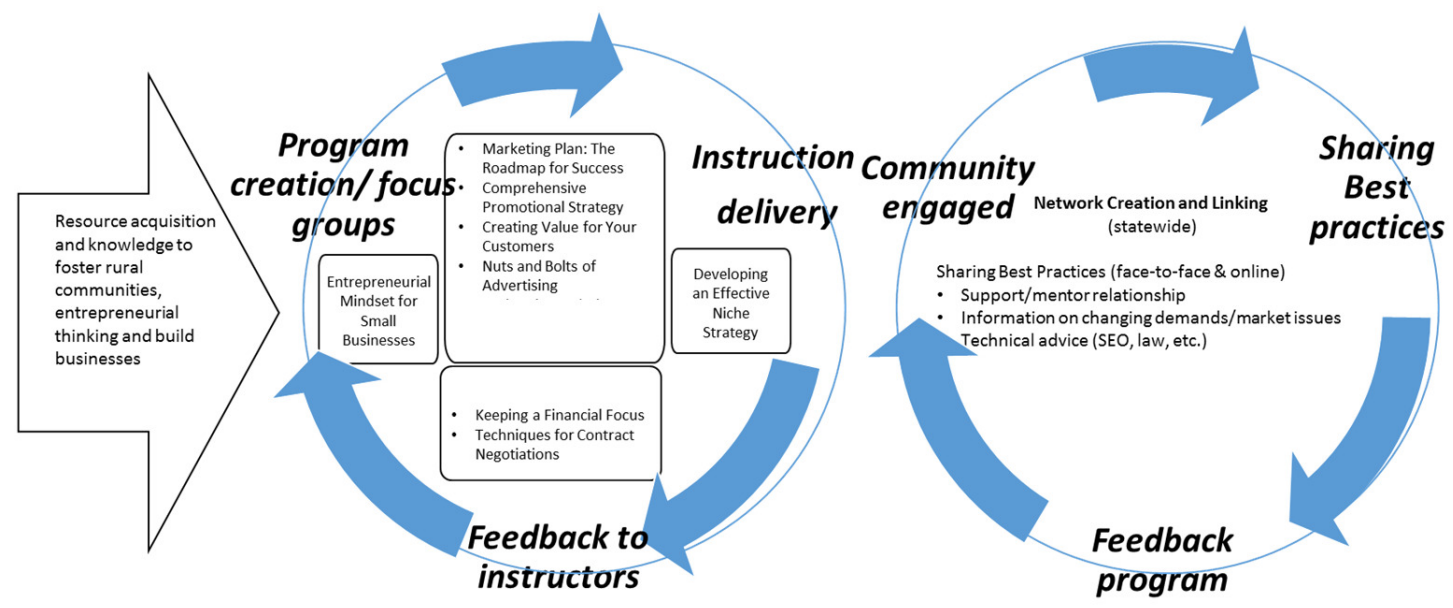

Figure 2. Model of Double-Loop Learning for Rural Communities

has made me realize how we are all in the same boat." Susan, Greensberg, KS

\section{Discussion}

The need for rural regions to strengthen their local innovation systems in developing enterprises has been suggested as an important area for improving regional competitive advantage (Rowe, 2009). This study contributes to the existing understanding regarding the importance of programmatic interventions in rural communities by providing locally relevant education and develop entrepreneurial skillsets. In particular, this paper provides three important learning takeaways. First, there are differences between rural and urban small businesses. We used an exploratory methodology to develop a program that tried to uniquely address the unique contexts of local rural business owners. Designing any program must take into consideration the local area needs. In addition, while we noted some literature that acknowledged these differences, there is not a wide scale development of what these differences are or how to properly take these into consideration. One recent addition to the literature provides a nuanced typology of the differences between rural and urban regions based on such factors as the extent of remoteness and land use of various regions (Laurin et al., 2020). They suggest that remoteness, not just a broad characterization of rurality, is an important aspect of firm difference that must be considered in order to understand performance and skill attainment. We believe that more research studying rural vs. urban SME's is needed, to inform policy makers, educators and business practitioners.
Second, after developing the initial Certificate program structure, it was determined that incorporating feedback for continuous program evolution is important as small business needs continuously change or have unique attributes in different regional areas. This can be challenging for universities and educators who look to benefit from the development of learning economies that come from standardized or routinized learning content. However, for the programs to continue to be received well in the rural communities, programs must be adaptable and delivered in real time using relevant content. This requires extensive faculty schedule coordination and a strong desire to have ensure expert faculty is available.

Lastly, a key outcome of the program is the development of stronger network relationships between regional business owners. Geographic proximity to a business network or cluster has been shown to have important performance implications for rural small businesses. Social capital developed through a network of regional network partners is related to relational and informational benefits that can be used by small businesses (Steinfield et al., 2010). In addition, proximity or engagement with a business network provides an entrepreneurial ecosystem for firms to be benefit from knowledge spillovers, common labor pools and value chain clusters (Scorsone, 2002). We feel the added benefit of working and learning with other rural business owners as co-participants of the program has proven to be invaluable to the local communities where the program has been implemented. Finally, we believe the benefit of the Rural Certificate Program has become even more important as the impact on small businesses from the COVID-19 pandemic is only beginning to be understood. 


\section{REFERENCES}

Dahlstrom, T. R., \& Talmage, C. A. (2018).

Entrepreneurial skills for sustainable small business: An exploratory study of SCORE, with comparison. Community Development, 49(4), 450-468. https://doi.o rg/10.1080/15575330.2018.1491613

Deller, S. C., \& Conroy, T. (2017). Business survival rates across the urban-rural divide. Community Development, 48(1), 67-85. https://doi.org/10.1080/15 $\underline{575330.2016 .1246459}$

Emery, M., Wall, M., \& Macke, D. (2004). From theory to action: Energizing entrepreneurship strategies to aid distressed communities grow their own. Journal of Community Development Society, 35(1), 82-96. http s://doi.org/10.1080/15575330409490123

Farja, Y., Gimmon, E., \& Greenberg, Z. (2017). The developing in the developed: Rural SME growth in Israel. International Journal of Entrepreneurship Innovation, 18(1), 36-46. https://doi.org/10.1177/1465 $\underline{750316686239}$

Farm Aid. (2014, October). Funding Opportunities. FarmAid.

Galli-Debicella, A. (2020). The efficacy of SBA loans on small firm survival rates. Journal of Small Business Strategy, 30(2), 26-34.

Garrido-Lopez, M., Hillon, Y. C., Cagle, W., \& Wright, E. (2018). Project-based strategic management education: A client perspective on key challenges. Journal of Small Business Strategy, 28(2), 68-79.

How GSA Helps Small Businesses. (2014, October 10). How GSA Helps Small Businesses.

Kansas Department of Commerce. (2014, October 10). Live Edit.

Laurin, F., Pronovost, S., \& Carrier, M. (2020). The end of the urban-rural dichotomy? Towards a new regional typology for SME performance. Journal of Rural Studies, 80, 53-75. https://doi.org/10.1016/j.jrur stud.2020.07.009

Love, H., \& Powe, M. (2020, December). Rural small businesses need local solutions to survive. https://ww w.brookings.edu/research/rural-small-businesses-nee d-local-solutions-to-survive/

Lyee, N., \& Cowling, M. (2015). Do rural firms perceive different problems? Geography, sorting and barriers to growth in UK SMEs. Environment and Planning $C$ : Government and Policy, 33(1), 25-42.
Martin, L. M., Warren-Smith, I., Schofield, C., \& Millman, C. (2013). Exploring SME advice and training needs for entrepreneurial rural firms. The International Journal of Entrepreneurship and Innovation, 14(2), 95-102. https://doi.org/10.5367/ije i. 2013.0110

NetworkKansas. (2020, October 10). NetworkKansas.

Phillipson, J., Tiwasing, P., Gorton, M., Maioli, S., Newbery, R., \& Turner, R. (2019). Shining a spotlight on small rural businesses: How does their performance compare with urban? Journal of Rural Studies, 68, 230-239. https://doi.org/10.1016/j.jrurstu d.2018.09.017

Rowe, J. E. (2009). The importance of theory: Linking theory to practice. Theories of Economic Development, $1-26$.

Rubach, M. J., \& McGee, J. E. (2001). The Competitive Behaviors of Small Retailers: Examining the Strategies of Local Merchants in Rural America. Journal of Small Business Strategy, 12(2), 65-81.

Scorsone, E. (2002). Industrial clusters: Enhancing rural economies through business linkages. Mississippi State, Mississippi, Southern Rural Development Center. htt p://srdc.msstate.edu/publications/scorsone.pdf

Senge, P. (2006). The Fifth Discipline: The Art \& Practice of the Learning Organization. Doubleday.

Steinfield, C., Scupola, A., \& López-Nicolás, C. (2010). Social capital, ICT use and company performance: Findings from the Medicon Valley Biotech Cluster. Technological Forecasting and Social Change, 77(7), 1156-1166. https://doi.org/10.1016/j.techfore.2010.0 $\underline{3.004}$

The U.S. Small Business Administration. (2019, September). 2019 Frequently Asked Questions about Small Business. https://advocacy.sba.gov/2019/09/24/f requently-asked-questions-about-small-business/

USDA Rural Development-KS Homepage. (2014, October). USDA Rural Development-KS Homepage.

USDA Rural Development-Subject. (2014, October). Rural Development Grant Assistance.

Vey, J. S., \& Love, H. (2019, November). A framework to create connected, vibrant and inclusive communities. htt ps://www.brookings.edu/research/transformative-pla cemaking-a-framework-to-create connected-vibrantand-inclusive-communities/ 